\title{
Conservation of 'Pedro Sato' guavas under treatment with 1-methylcyclopropene
}

\author{
Eliane Bassetto ${ }^{(1)}$, Angelo Pedro Jacomino $^{(1)}$ and Ana Luiza Pinheiro(1)
}

\begin{abstract}
(1)Escola Superior de Agricultura Luiz de Queiroz, Dep. de Produção Vegetal, Caixa Postal 9, CEP 13418-900 Piracicaba, SP, Brazil. E-mail: ebassett@esalq.usp.br, jacomino@esalq.usp.br, alpinhei@esalq.usp.br
\end{abstract}

\begin{abstract}
The search for techniques that extend shelf life of guava (Psidium guajava) fruits, and reduce its postharvest losses is desirable. The objective of this work was to evaluate the effects of concentrations of competitive ethylene antagonist 1-methylcyclopropene (1-MCP) on conservation of 'Pedro Sato' guava fruits. Treatments consisted of $0,100,300$ or $900 \mathrm{~nL} \mathrm{~L}^{-1}$ of 1 -MCP for 3 hours followed by storage at $25^{\circ} \mathrm{C}$, and $10^{\circ} \mathrm{C}$ with $90 \pm 5 \% \mathrm{RH}$. The application of $900 \mathrm{~nL} \mathrm{~L}{ }^{-1} 1-\mathrm{MCP}$ for 3 hours was efficient in delaying loss of skin color, and in keeping fruit firmness at both storage temperatures. The $300 \mathrm{~nL} \mathrm{~L}^{-1}$ of 1-MCP concentration was efficient in delaying skin color loss only when fruits were stored at $10^{\circ} \mathrm{C}$. The effect of 1 -MCP was quite significant on the reduction of rot incidence at both storage temperatures. The respiratory rate was lower in fruits treated with 300 and $900 \mathrm{~nL} \mathrm{~L}^{-1}$ of $1-\mathrm{MCP}$ during storage at $25^{\circ} \mathrm{C}$. The product was efficient in delaying the ripening of fruits, and the concentration of $900 \mathrm{~nL} \mathrm{~L}^{-1}$ showed the best effect.
\end{abstract}

Index terms: Psidium guajava, temperature, conservation, postharvest.

\section{Conservação de goiabas ‘Pedro Sato’ tratadas com 1-metilciclopropeno}

\begin{abstract}
Resumo - A pesquisa de técnicas que ampliem o período de conservação da goiaba (Psidium guajava) e reduzam as perdas pós-colheita é importante, por causa de sua perecibilidade. O objetivo deste trabalho foi avaliar os efeitos e concentrações do antagonista competitivo do etileno, 1-metilciclopropeno (1-MCP), na conservação de goiabas 'Pedro Sato'. Os frutos foram tratados com 0, 100, 300 e $900 \mathrm{~nL} \mathrm{~L}^{-1}$ de 1-MCP durante três horas, e armazenados a $25^{\circ} \mathrm{C}$ e a $10^{\circ} \mathrm{C}$ com $90 \pm 5 \%$ UR. A aplicação de $900 \mathrm{~nL} \mathrm{~L}^{-1}$ de 1 -MCP foi eficiente em retardar a perda de coloração da casca e em manter a firmeza dos frutos, nas duas temperaturas de armazenamento. A concentração de $300 \mathrm{~nL} \mathrm{~L}{ }^{-1}$ de 1-MCP retardou a perda de coloração da casca, quando os frutos foram armazenados a $10^{\circ} \mathrm{C}$. O efeito do 1-MCP foi bastante significativo em diminuir a incidência de podridões, nas duas temperaturas de armazenamento. A taxa respiratória foi menor nos frutos tratados com 300 e $900 \mathrm{~nL} \mathrm{~L}^{-1}$ de 1-MCP, durante o armazenamento a $25^{\circ} \mathrm{C}$. O 1-MCP foi eficiente em retardar o amadurecimento dos frutos e a concentração de $900 \mathrm{~nL} \mathrm{~L}^{-1}$ produziu o melhor resultado.
\end{abstract}

Termos para indexação: Psidium guajava, temperatura, conservação, pós-colheita.

\section{Introduction}

Guava is a highly perishable fruit that shows intense metabolic activity. Guava fruit becomes fully ripe between three and five days at room temperature (Gongatti Neto et al., 1996). Due to such perishability, the control of fruit ripening is fundamental for increasing shelf life after harvest. The main factors depreciating postharvest quality in guava are fast loss of green color, excessive softening, high rot incidence and loss of turgidity (Jacomino et al., 2001).

Storage under low temperatures has been considered the most efficient method to maintain quality of most fruits and vegetables due to its effects on reducing respiration rate, transpiration, ethylene production, ripening, senescence and rot development (Hardenburg et al., 1986). In climacteric fruits, like most guava varieties, the reduction of temperature delays the climacteric peak and, consequently, ripening (Kader, 1992).

The recent finding that 1-methylcyclopropene (1-MCP) interferes with ethylene link to its binding site represents a new and powerful tool for postharvest management of climacteric fruits (Sisler \& Serek, 1997). It has been demonstrated that the inhibition of the ethylene action delays ripening and senescence in several species of fruits, such as custtard apple (Benassi et al., 2003), guava (Bassetto et al., 2002), papaya (Jacomino 
et al., 2002), peach (Kluge \& Jacomino, 2002), apple (Rupasinghe et al., 2000), avocado (Feng et al., 2000), banana (Sisler \& Serek, 1997; Golding et al., 1998; Jiang et al., 1999), strawberry (Ku \& Wills, 1999) and tomato (Sisler \& Serek, 1997).

The recommendation regarding treatment with 1-MCP generally sets an exposure time of 12 hours. However, when considering postharvest of guava fruit a fast treatment of 3 hours at most is suggested.

The purpose of this work was to evaluate the effects of 1-MCP concentrations on 'Pedro Sato' guavas treated for 3 hours, stored at room temperature and under refrigeration.

\section{Material and Methods}

'Pedro Sato' guava fruits were harvested and taken to the Crop Production Department of Esalq-USP, Piracicaba, SP, Brazil. Fruits showing no defects at maturation stage characterized by skin color change from dark to light green and weighing $165 \pm 10$ g were used.

The commercial product Smartfresh, wetable powder, containing $0.14 \%$ 1-MCP active ingredient was used. Application was carried out in hermetic chambers in which fruits were exposed to 1-MCP at concentrations of $0,100,300$ and $900 \mathrm{~nL} \mathrm{~L}^{-1}$ for 3 hours at $24^{\circ} \mathrm{C}-25^{\circ} \mathrm{C}$ (first experiment) and at $10^{\circ} \mathrm{C}$ (second experiment). Predetermined amounts of Smartfresh were placed in flasks with lids and $20 \mathrm{~mL}$ of distilled water at $50^{\circ} \mathrm{C}$ were added to each flask, which was shaken until complete dissolution. Then, flasks were opened inside the chambers, which were immediately closed to avoid gas losses. After treatments the chambers were opened, fruits were stored under room conditions $\left(25^{\circ} \mathrm{C}\right)$ for 2,4 , 6 and 8 days and put under refrigeration $\left(10^{\circ} \mathrm{C}\right)$ for 4,8 , 12 and 16 days.

The experimental statistical design was completely randomized in a factorial design. The factors studied were $1-\mathrm{MCP}$ concentrations and storage periods. Fruits stored at $25^{\circ} \mathrm{C}$ were analyzed at the end of each storage period, and those stored at $10^{\circ} \mathrm{C}$ were kept at $25^{\circ} \mathrm{C}$ for two days before being analyzed. For each treatment, four replications were used with four fruits per plot, totaling 512 fruits.

The variables analyzed were: a) skin and pulp colors determined with colorimeter, and results were expressed in hue angle $\left({ }^{\circ} \mathrm{h}\right)$ and chroma $(\mathrm{C})$, respectively; skin color was evaluated by means of two readings on opposite sides along the fruit's equatorial region, while pulp color was assessed by means of one reading in the middle of the fruit's placental region after transversal sectioning; b) mass loss was determined by percentage difference between initial and final masses of each replication; c) pulp firmness was determined with a $8 \mathrm{~mm}$-point digital penetrometer; two readings were carried out on opposite sides along fruit equatorial region, and results were expressed in Newton (N); d) total titratable acidity (TTA) was determined from $10 \mathrm{~g}$ of puree diluted with $90 \mathrm{~mL}$ of water, titrated with $0.1 \mathrm{~N} \mathrm{NaOH}$ to $\mathrm{pH} 8.1$ and expressed in percentage of citric acid (Carvalho et al., 1990); e) amount of ascorbic acid was determined by titration (Carvalho et al., 1990), and results were expressed in mg of ascorbic acid per $100 \mathrm{~g}$ of pulp; f) total soluble solids amount (TSS) was determined by direct reading of centrifuged fruit samples in a digital refractometer, and results were expressed in ${ }^{\circ} \mathrm{Brix}$; g) rot incidence was evaluated by affected fruit count, with results expressed as a percentage of affected fruits; and h) respiratory rate was determined by incubating fruits of known mass and volume in hermetic flasks of known volume; after one hour, $\mathrm{CO}_{2}$ concentration in flasks was determined by a Check Mate $9900 \mathrm{O}_{2} / \mathrm{CO}_{2} \mathrm{PBI}$ Dansensor A/S, DK-4100 gas analyzer, and respiratory rate results were expressed in $\mathrm{mL} \mathrm{CO}_{2} \mathrm{~kg}^{-1} \mathrm{~h}^{-1}$; five replications with three fruits per treatment were used.

A standard deviation analysis was applied to the results. Differences between two treatments exceeding two standard deviations were considered to be significant.

\section{Results and Discussion}

Fruits treated with $1-\mathrm{MCP}$ and stored at $25^{\circ} \mathrm{C}$ showed slower loss of green skin color than non-treated fruits (Figure 1). On the $4^{\text {th }}$ day of storage, non-treated fruits presented yellow color $\left(h^{\circ}=102\right)$; they were on their last suitable day for commercialization, while fruits from the remaining treatments retained greenish-yellow skin color. From the $4^{\text {th }}$ day of storage, there was fast loss of green color in fruits treated with 100 and $300 \mathrm{~nL} \mathrm{~L}^{-1}$ 1-MCP. Fruits treated with $900 \mathrm{~nL} \mathrm{~L}^{-1} 1$-MCP showed the greatest retention of skin color. On the $8^{\text {th }}$ day of storage these fruits were still slightly green.

Loss of green skin color is due to chlorophyll molecule breakdown by the chlorophyllase activity. The increase 
in the activity of this enzyme is generally associated with ethylene production during fruit ripening (Tucker, 1993). The product binds to the ethylene binding site in cells, inhibiting ethylene action on the physiologic processes of ripening (Serek et al., 1995). Therefore, loss of green color resulting from the normal ripening process was delayed by the application of 1-MCP. Green color retention in fruits treated with 1-MCP has also been observed in plums (Abdi et al., 1998), bananas (Golding et al., 1998), tomatoes (Dupille \& Sisler, 1995) and papayas (Jacomino et al., 2002).

Pulp was pink in the placental region at harvest (chroma $=34.5)$ and became intense red after ripening (chroma $=41.5$ to 43.0$)$. Chroma defines the variation in color intensity, with greater chroma values indicating more vivid colors. The fruit's pulp color was affected by the application of 1-MCP. Fruits treated with 1-MCP present slower increasing in the chroma of pulp color as
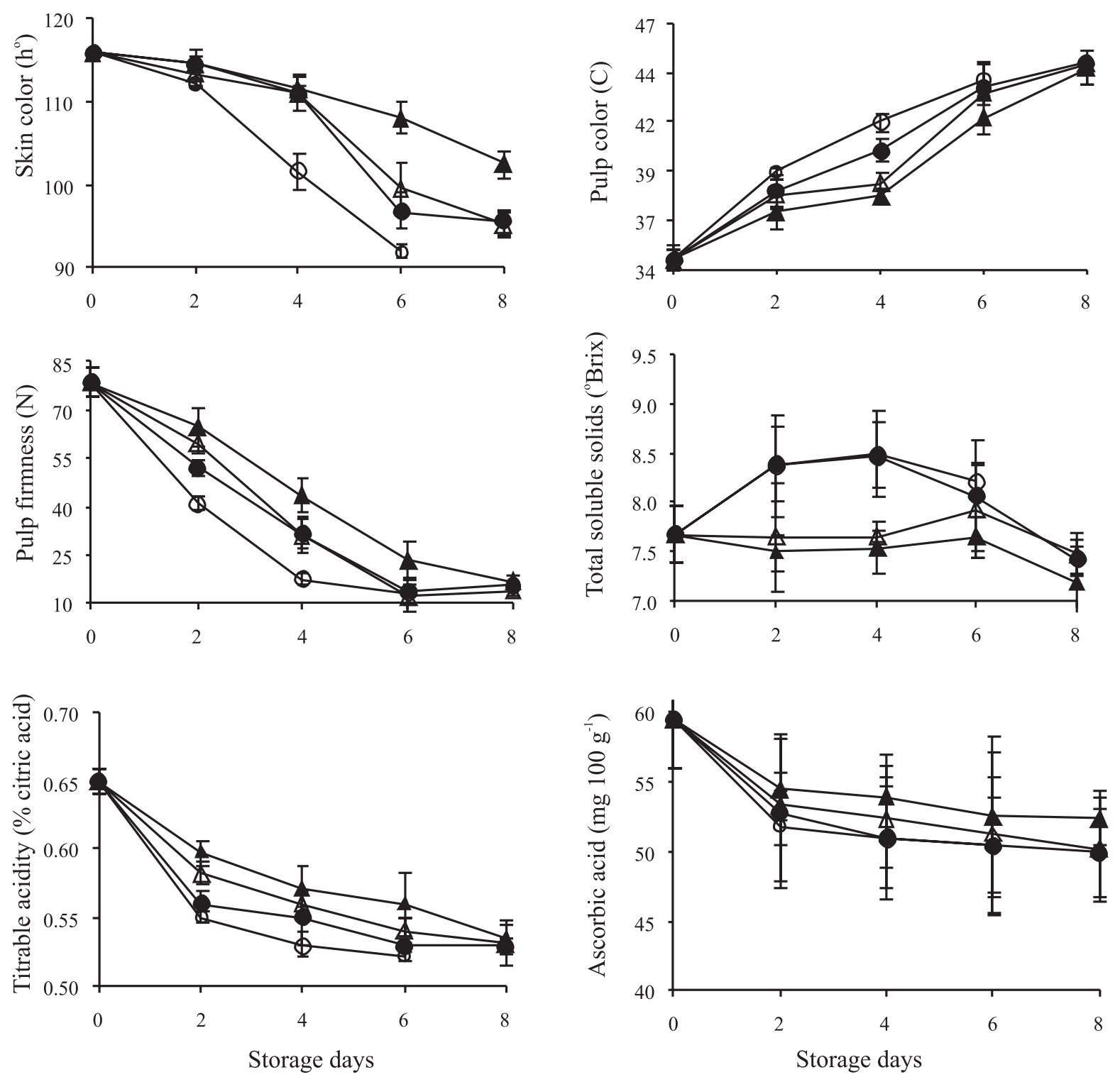

\begin{tabular}{|c|c|c|c|}
\hline$\bigcirc 0 \mathrm{~nL} \mathrm{~L}^{-1}$ & $100 \mathrm{~nL} \mathrm{~L}^{-1}$ & $\triangle 300 \mathrm{~nL} \mathrm{~L}^{-1}$ & $\Delta 900 \mathrm{~nL} \mathrm{~L}^{-1}$ \\
\hline
\end{tabular}

Figure 1. Physicochemical characteristics of 'Pedro Sato' guavas treated with 1-MCP for 3 hours, and stored at $25^{\circ} \mathrm{C}$. 
shown in Figure 1 . On the $6^{\text {th }}$ day of storage, there was little difference among treatments for pulp color. New ethylene binding sites were, probably, synthesized in the pulp, promoting fruit ripening and making color more vivid (increasing chroma) (Figure 1).

Guava fruits show high reduction in firmness during ripening, which constitutes a major conservation problem; treatment with 1-MCP efficiently preserved this quality characteristic. Non-treated guavas showed $78.7 \mathrm{~N}$ firmness at harvest and $17.0 \mathrm{~N}$ on the $4^{\text {th }}$ day of storage. Fruits treated with 100 or $300 \mathrm{~nL} \mathrm{~L}^{-1}$ reached values around $17.0 \mathrm{~N}$ firmness on the $6^{\text {th }}$ day of storage and those treated with $900 \mathrm{~nL} \mathrm{~L}^{-1}$ on the $8^{\text {th }}$ day (Figure 1).

Firmness of fruit pulp is determined by cohesion among pectins, and in ripening evolution pectinolytic enzymes turn insoluble into soluble pectin and promote fruits softening, which is one of the ripening processes most sensitive to ethylene (Lelièvre et al., 1997). Firmness increasing of fruits treated with $900 \mathrm{~nL} \mathrm{~L}^{-1} 1-\mathrm{MCP}$ is probably associated with reduction in the activity of pectinolytic enzymes induced by smaller ethylene action. Similar results were observed in apple (Fan et al., 1999), banana (Jiang et al., 1999) and papaya (Jacomino et al., 2002).

Soluble solids amount was lower in fruits treated with 300 and $900 \mathrm{~nL} \mathrm{~L}^{-1}$ 1-MCP (Figure 1), due to the fact that 1-MCP probably delays fruit ripening. The amount of sugars usually increases along with fruit ripening through biosynthesis processes or degradation of polysaccharides (Chitarra \& Chitarra, 1990). Lower amounts of soluble solids in fruits treated with 1-MCP were also verified in other studies (Watkins et al., 2000; Botrel, 2002).

The amount of organic acids usually decreases during ripening, because they are substrates of respiration (Wills et al., 1981). In general, amount of citric acid decreased during storage, which was more evident in fruits not receiving 1-MCP. In treated fruits, the higher was the regulator concentration, the greater was the retention of acidity (Figure 1).

Ascorbic acid amount ranged from $50 \mathrm{mg} 100 \mathrm{~g}^{-1}$ to $53 \mathrm{mg} 100 \mathrm{~g}^{-1}$ of pulp and was not influenced by 1-MCP (Figure 1).

The percentage of fruit rot during storage at $25^{\circ} \mathrm{C}$ was affected by 1-MCP treatment (Figure 2). Colletotrichum gloeosporioides was the most frequent fungus. Non-treated fruits showed high percentage of rot (above $30 \%$ ) on the $4^{\text {th }}$ day of storage. High percentages of rot were observed from the $6^{\text {th }}$ day of storage in fruits treated with 100 or $300 \mathrm{~nL} \mathrm{~L}^{-1} 1$-MCP, and from the $8^{\text {th }}$ day of storage in fruits treated with $900 \mathrm{~nL} \mathrm{~L}^{-1} 1$-MCP. In guava, postharvest rot increases along with ripening (Jacomino, 2001). Although 1-MCP is not a fungicide and does not have protective nor eradicating effect on pathogens, it shows indirect benefits in fungi control of fruit decaying by delaying ripening.

Only fruits treated with $900 \mathrm{~nL} \mathrm{~L}^{-1} 1$-MCP showed a considerable reduction in the respiratory rate at $25^{\circ} \mathrm{C}$, presenting values between $44 \mathrm{~mL}$ and $66 \mathrm{~mL} \mathrm{~kg}^{-1} \mathrm{~h}^{-1}$ $\mathrm{CO}_{2}$ (Figure 3). Fruits from the remaining treatments

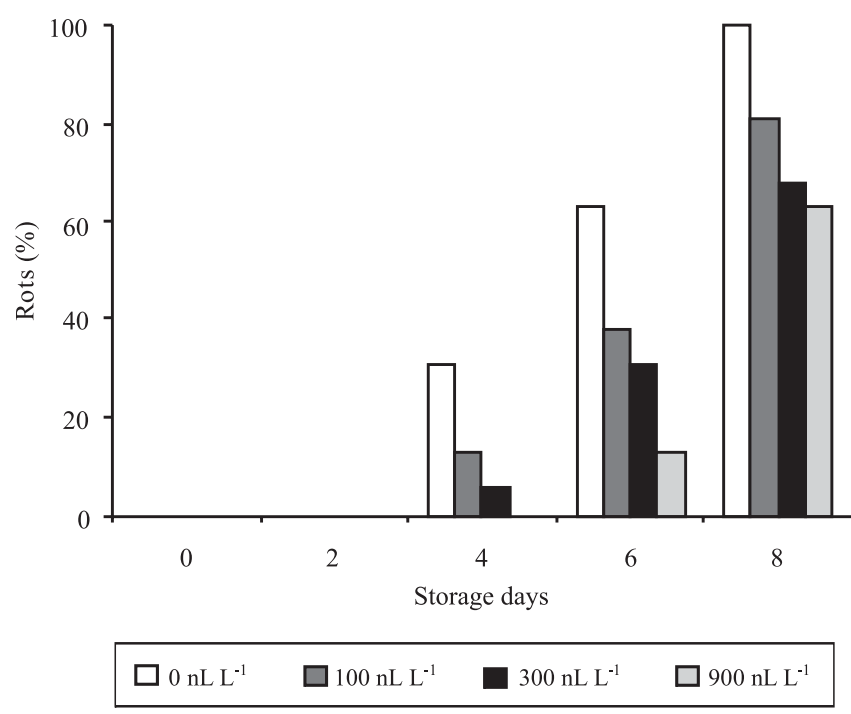

Figure 2. Rot incidence in 'Pedro Sato' guavas treated with 1-MCP for 3 hours, and stored at $25^{\circ} \mathrm{C}$.

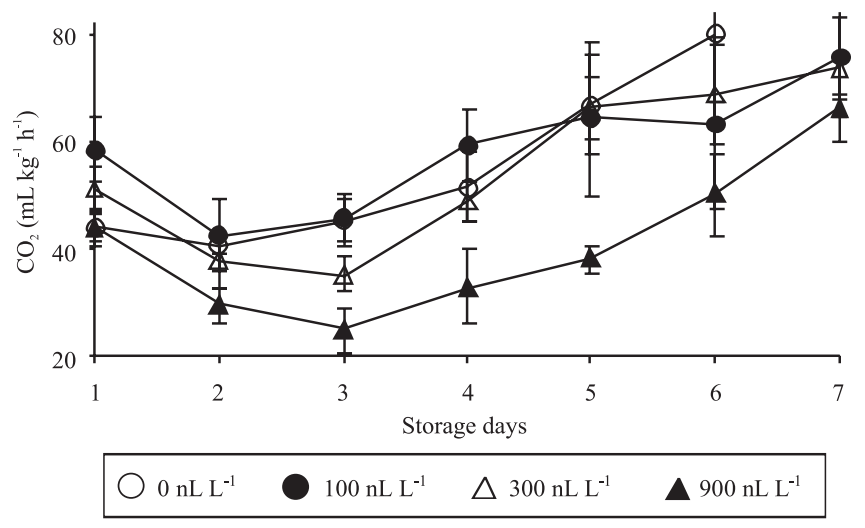

Figure 3. Respiratory rate of 'Pedro Sato' guavas treated with 1-MCP for 3 hours, and stored at $25^{\circ} \mathrm{C}$. 
showed similar respiratory activity among them with values between $51 \mathrm{~mL}$ and $80 \mathrm{~mL} \mathrm{~kg}^{-1} \mathrm{~h}^{-1} \mathrm{CO}_{2}$. When applied at the right time 1-MCP blocks ethylene binding sites and prevents the ethylene effects, such as the increase in respiratory rate (Serek et al., 1995). Conservation of a vegetable product is inversely related to the respiratory rate and, in many cases, also to ethylene production rate (Kader, 1994). The reduction in respiratory rate accounts for better conservation in fruits treated with $900 \mathrm{~nL} \mathrm{~L}^{-1} 1$-MCP. Lower respiratory rates in fruits treated with 1-MCP were also observed by other authors (Abdi et al., 1998; Golding et al., 1998; Fan et al., 1999; Jiang et al., 1999; Jacomino et al., 2002).

As for fruits stored at $10^{\circ} \mathrm{C}$, little reduction in green skin color was observed while they were under refrigeration (Figure 4). After being transferred to room conditions $\left(25^{\circ} \mathrm{C}\right)$, non-treated fruits or fruits treated with $100 \mathrm{~nL} \mathrm{~L}^{-1}$ showed evident loss of green color, which intensified with lengthening of the storage period. Treatments 300 and $900 \mathrm{~nL} \mathrm{~L}^{-1}$ effectively retained the green color of fruits, so that even after two days in room conditions guavas were predominantly green, presenting average values for $\mathrm{h}^{\circ}$ from 107 to 110 , regardless refrigerated storage period.

Storage under low temperatures reduces enzymatic activities (Hardenburg et al., 1986). Therefore, the loss of green color, resulting from normal ripening process, was delayed in refrigerated storage and because of 1-MCP application. The retention of skin color in fruits treated with 1-MCP and stored in refrigerated conditions was also verified in pears (Fan et al., 2002).

Treatment with 1-MCP efficiently delayed loss of pulp firmness during $10^{\circ} \mathrm{C} / 25^{\circ} \mathrm{C}$ refrigerated storage only at $900 \mathrm{~nL} \mathrm{~L}^{-1}$ concentration (Figure 5). Fruits treated with $100 \mathrm{~nL} \mathrm{~L}^{-1}$ or $300 \mathrm{~nL} \mathrm{~L}^{-1}$ showed fast loss of firmness not differing from non-treated fruits on the $8^{\text {th }}$ day of storage. Fruits treated with $900 \mathrm{~nL} \mathrm{~L}^{-1}$ showed higher firmness than other treatments during all storage periods. Greater firmness in fruits, treated with $900 \mathrm{~nL} \mathrm{~L}^{-1}$ 1-MCP, is probably associated with reduction in the activity of pectinolytic enzymes induced by lower ethylene activity, and low storage temperature (Lelièvre et al., 1997).

Total titratable acidity was influenced by 1-MCP. Fruits treated with 1-MCP showed greater amounts of citric acid than non-treated ones, regardless 1-MCP concentration used (Figure 5).

Retention of fruit ripening due to refrigerated storage and due to the use of 1-MCP promoted lower incidence of fruit rots. Fruits kept at $10^{\circ} \mathrm{C}$ showed low rot incidence. Some rot incidence was observed only in the treatment without 1 -MCP on the $16^{\text {th }}$ day of storage (incidence $<15 \%$ ). When fruits treated with 1-MCP remained at $25^{\circ} \mathrm{C}$ for two days, rot percentage was low $(<20 \%)$ until the $12^{\text {th }}$ day of storage, while non-treated fruits showed $63 \%$ of rot incidence (Figure 5). Jacomino et al. (2002) also observed lower rot incidence in papayas
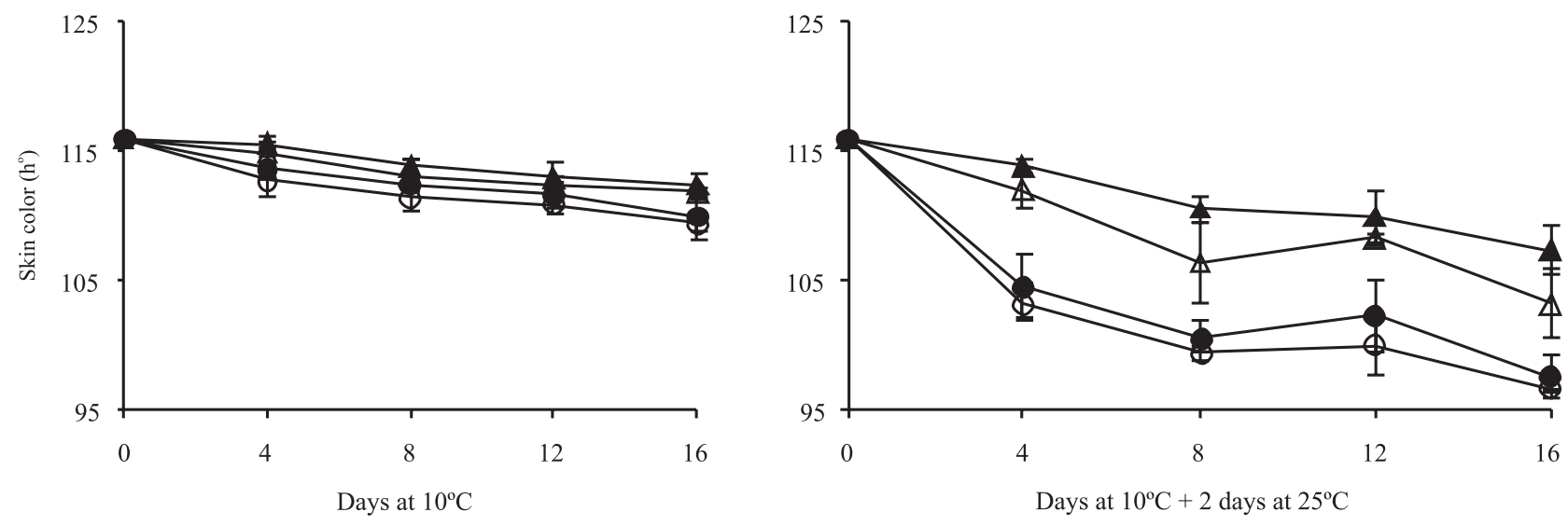

$$
\bigcirc 0 \mathrm{~nL} \mathrm{~L}^{-1} \quad \mathrm{~N}_{100 \mathrm{~nL}^{-1}} \quad \Delta 300 \mathrm{~nL} \mathrm{~L}^{-1} \quad \boldsymbol{\Delta} 900 \mathrm{~nL} \mathrm{~L}^{-1}
$$

Figure 4. Skin color of 'Pedro Sato' guavas treated with 1-MCP for 3 hours, and stored at $10^{\circ} \mathrm{C}$ and at $10^{\circ} \mathrm{C}+2$ days at $25^{\circ} \mathrm{C}$. 
treated with 1-MCP. Colletotrichum gloeosporioides was identified as the main fungus causing rot in guavas.

Pulp color, soluble solids amount and vitamin $\mathrm{C}$ amount were not influenced by $1-\mathrm{MCP}$ at $10^{\circ} \mathrm{C} / 25^{\circ} \mathrm{C}$ storage temperatures (Figure 5).
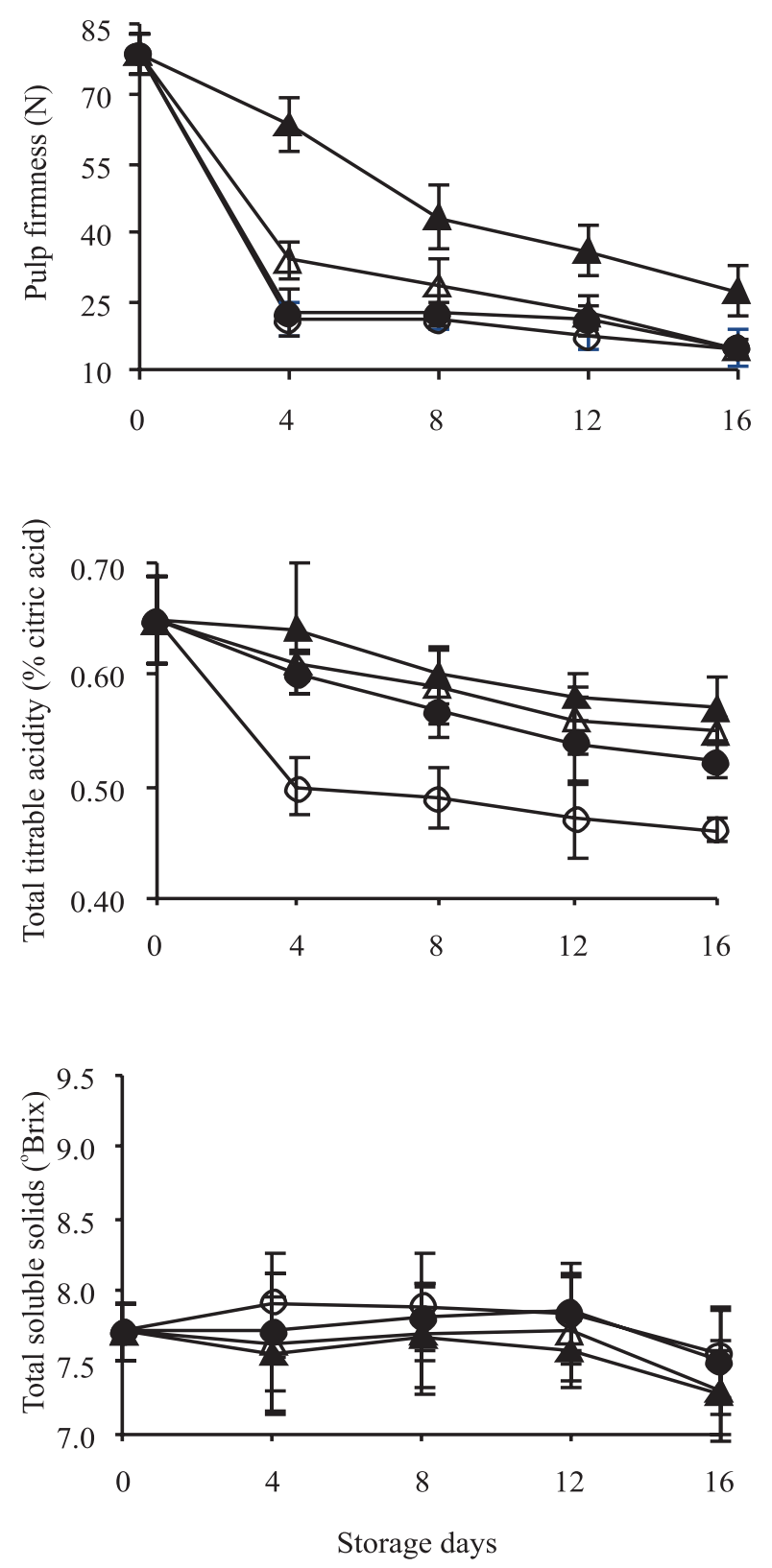

Fruits stored at $10^{\circ} \mathrm{C}$ showed little variation in respiratory rate along the storage period, with values ranging from $10 \mathrm{~mL}$ to $15 \mathrm{~mL} \mathrm{~kg}^{-1} \mathrm{~h}^{-1} \mathrm{CO}_{2}$ regardless treatment (Figure 6). Such values were much lower than those observed for fruits kept at $25^{\circ} \mathrm{C}$.
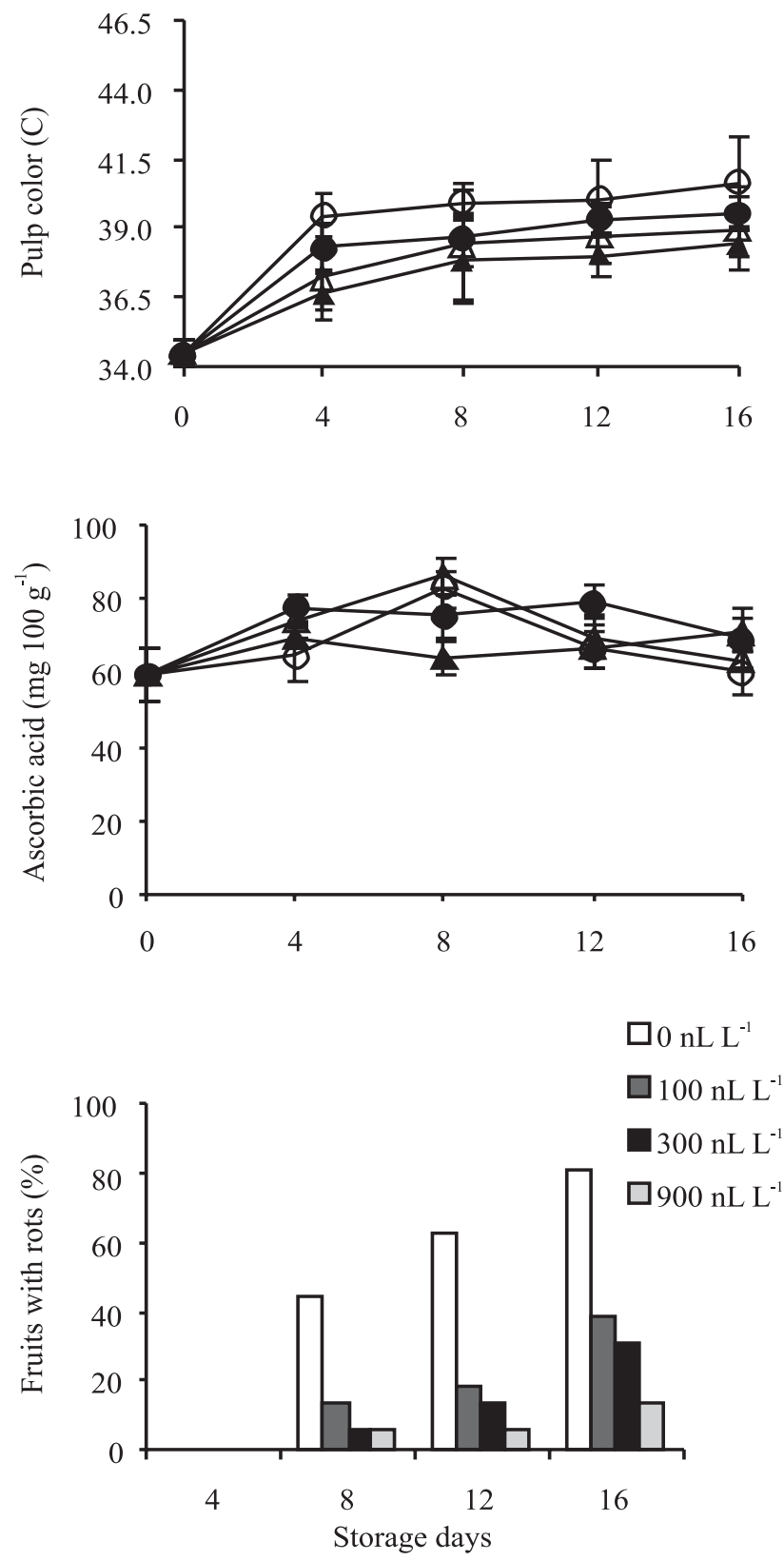

$\triangle 300 \mathrm{~nL} \mathrm{~L}^{-1}$

Figure 5. Physicochemical characteristics of 'Pedro Sato' guavas treated with 1-MCP for 3 hours, and stored at $10^{\circ} \mathrm{C}+2$ days at $25^{\circ} \mathrm{C}$. 


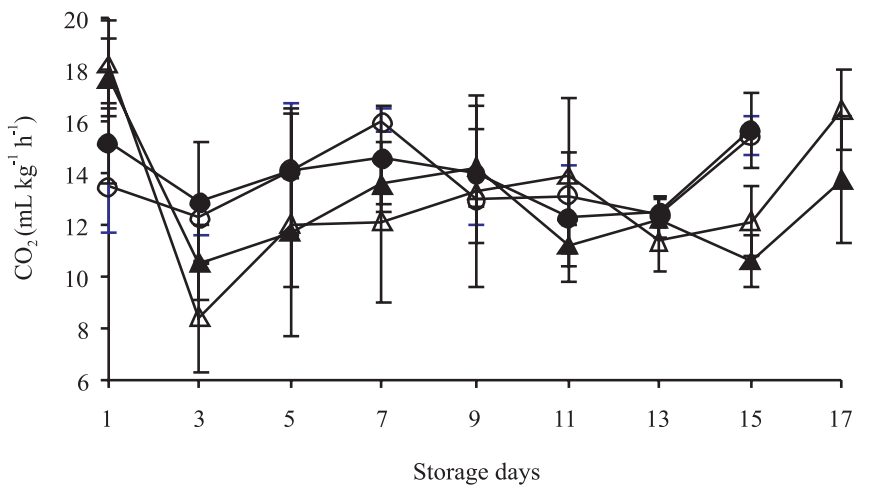

$\bigcirc 0 \mathrm{nLL}^{-1} \bigcirc 100 \mathrm{nLL}^{-1} \quad \triangle 300 \mathrm{nLL}^{-1} \quad \Delta 900 \mathrm{nLL}^{-1}$

Figure 6. Respiratory rate of 'Pedro Sato' guavas treated with 1-MCP for 3 hours, and stored at $10^{\circ} \mathrm{C}$.

\section{Conclusions}

1. Treating fruits with 1-MCP for 3 hours is efficient in delaying ripening in guavas fruits.

2. The concentration $900 \mathrm{~nL} \mathrm{~L}^{-1} 1-\mathrm{MCP}$ is efficient in delaying ripening under $10^{\circ} \mathrm{C}$ and $25^{\circ} \mathrm{C}$ storage temperatures.

\section{Acknowledgements}

To AgroFresh Inc., especially to Mr. Walter S.P. Pereira, for providing the 1-MCP samples; to Val Fruits Company, for providing the guava fruits.

\section{References}

ABDI, N.; McGLASSON, W.B.; HOLFORD, P.; WILLIAMS, M.; MIZRAHI, Y. Responses of climateric and suppressed-climateric plums to treatment with propylene and 1-methylcyclopropene. Postharvest Biology and Technology, v.14, p.29-39, 1998.

BASSETTO, E.; SESSO, T.M.; JACOMINO, A.P.; KLUGE, R.A. Efeito de 1-MCP e prochloraz na conservação de goiabas 'Pedro Sato’. Revista Iberoamericana de Tecnologia Postcosecha, v.4, p.122-127, 2002.

BENASSI, G.; CORREA, G.A.S.F.; KLUGE, R.A.; JACOMINO, A.P. Shelf life of custard apple treated with 1-methylcyclopropene: an antagonist to the ethylene action. Brazilian Archives of Biology and Technology, v.46, p.115-119, 2003.

BOTREL, N.; FREIRE, M.J.; VASCONCELOS, R.M.; BARBOSA, H.T.G. Inibição do amadurecimento da banana 'Prata-Anã' com a aplicação do 1-metilciclopropeno. Revista Brasileira de Fruticultura, v.24, p.53-56, 2002.
CARVALHO, C.R.L.; MANTOVANI, D.M.B.; CARVALHO, P.R.N.; MORAES, R.M.M. Análises químicas de alimentos: manual técnico. Campinas: ITAL, 1990. 121p.

CHITARRA, M.I.F.; CHITARRA, A.B. Pós-colheita de frutas e hortaliças: fisiologia e manuseio. Lavras: Esal, Faepe, 1990. 320p.

DUPILLE, E.; SISLER, E.C. Effects of ethylene receptor antagonist on plant material. In: AIT-OUBAHOU, A.; EL-OTMANI, M. (Ed.). Postharvest, pathology and technologies for horticultural commodities: recent advances. Agadir: Institute Agronomique et Veterinaire Hassan II, 1995. p.294-301.

FAN, X.; ARGENTA, L.; MATTHEIS, J.P. Interactive effects of 1-MCP and temperature on 'Elberta' peach quality. HortScience, v.37, p.134-138, 2002.

FAN, X.; BLANKENSHIP, S.M.; MATTHEIS, J.P. 1-methylcyclopropene inhibits apple ripening. Journal of the American Society for Horticultural Science, v.124, p.690-695, 1999.

FENG, X.; APELBAUM, A.; SISLER, E.C.; GOREN, R. Control of ethylene responses in avocado fruit with 1-methylcyclopropene. Postharvest Biology and Technology, v.20, p.43-150, 2000.

GOLDING, J.B.; SHEARER, D.; WYLLIE, S.G.; McGLASSON, W.B. Application of 1-MCP and propylene to identify ethylenedependent ripening process in mature banana fruit. Postharvest Biology and Technology, v.14, p.87-98, 1998.

GONGATTI NETO, A.; GARCIA, A.E.; ARDITO, E.F.G. Goiaba para exportação: procedimentos de colheita e pós-colheita. Brasília: Embrapa-SPI, 1996. 35p. (Frupex, 20).

HARDENBURG, R.E.; WATADA, A.E.; WANG, C.Y. The commercial storage of fruits, vegetables, and florist, and nursery stocks. Washington: USDA, 1986. 130p. (USDA. Agriculture Handbook, 66).

JACOMINO, A.P.; KLUGE, R.A.; BRACKMANN, A.; CASTRO, P.R.C. Amadurecimento e senescência de mamão com 1-metilciclopropeno. Scientia Agricola, v.59, p.303-308, 2002.

JACOMINO, A.P.; SARANTÓPOULOS, C.I.G.L.; SIGRIST, J.M.M.; KLUGE, R.A.; MINAMI, K. Sensorial characteristics of 'Kumagai' guavas submitted to passive modified atmosphere in plastic packages. Journal of Plastic Film \& Sheeting, v.17, p.6-21, 2001.

JIANG, Y.; JOYCE, D.C.; MACNISH, A.J. Responses of banana fruit to treatment with 1-methylcyclopropene. Plant Growth Regulation, v.28, p.77-82, 1999.

KADER, A.A. Postharvest technology of horticultural crops. Oakland: University of California, 1992. 269p.

KADER, A.A. Postharvest technology of horticultural crops. Oakland: University of California, 1994. 296p.

KLUGE, R.A.; JACOMINO, A.P. Shelf life of peaches treated with 1-methylcyclopropene. Scientia Agricola, v.59, p.69-72, 2002.

KU, V.V.V.; WILLS, R.B.H.; BEN-YEHOSHUA, S. 1-Methylcyclopropene can differentially affect the postharvest life of strawberries exposed to ethylene. HortScience, v.34, p.119-120, 1999.

LELIÈVRE, J.M.; LATCHÉ, A.; JONES, B.; BOUZAYEN, M.; PECH, J.C. Ethylene and fruit ripening. Physiologia Plantarum, v.101, p.727-739, 1997. 
RUPASINGUE, H.P.V.; MURR, D.P.; PALIYATH, G.; SKOG, L. Inhibitory effect of 1-MCP on ripening and superficial scald development in 'McIntosh' and 'Delicious' apples. Journal of Horticultural Science \& Biotechnology, v.75, p.271-276, 2000.

SEREK, M.; SISLER, E.C.; REID, M.S. 1-Methylcyclopropene, a novel gaseous inhibitor of ethylene action, improves the life of fruit, cut flowers and potted plants. Acta Horticulturae, n.394, p.337345, 1995.

SISLER, E.C.; SEREK, M. Inhibitors of ethylene responses in plants at the receptors level: recent developments. Physiologia Plantarum, v.100, p.577-582, 1997.
TUCKER, G.A. Introduction. In: SEYMOR, G.B.; TAYLOR, J.E.; TUCKER, G.A. Biochemistry of fruit ripening. London: Champmal \& Hall, 1993. cap.1, p.2-51.

WATKINS, C.B.; NOCK, J.F.; WHITAKER, B.D. Responses of early, mid and late season apple cultivars to postharvest application of 1-methylcyclopropene (1-MCP) under air and controlled atmosphere storage conditions. Postharvest Biology and Technology, v.19, p.17-32, 2000.

WILLS, R.H.H.; LEE, T.H.; GRAHAM, W.B.; HALL, E.G. Postharvest: an introduction to the physiology and handling of fruit and vegetables. Kensington: New South Wales University Press, 1981. 161p.

Received on April 2, 2004 and accepted on November 25, 2004 